\title{
The Pharmaceutical Year that was, 2016
}

\author{
Anthony W. Fox ${ }^{1}$
}

Published online: 24 October 2016

(C) Springer International Publishing Switzerland 2016

At the time of writing (we go to press mid-October for this issue), it seems to have been a year of two halves. It is probably not good that what seems like the 'second half' has lasted only about 12 weeks!

Three pharmaceutical issues dominated the press in USA during the first half of the year. The first was that politicians became interested in opioid (over-)prescribing. It has been known for a long time that US and Canadian primary care practitioners are not confident with regard to prescribing opioids for non-malignant chronic pain syndromes [1]. In 2012, a US Food and Drug Administration (FDA) advisory committee had voted against mandatory training before prescribing products such as long-acting oxycodone and methadone. This had been generally supported by the pharmaceutical industry, which had already implemented prescriber training on a voluntary basis, but making this mandatory had also been opposed by the American Medical Association [2]. In February 2016, possibly as a result of Congressional pressure, the Agency issued a press release that announced that the problem was now an epidemic, and listed several risk management strategies that would now be required [3]. A further FDA advisory committee (14 May, 2016) has now recommended mandatory prescriber training, the precise design of which will soon be known [2].

Anthony W. Fox

Tony.Fox@kcl.ac.uk

1 Pharmaceutical Medicine Group, Faculty of Life Sciences and Medicine, Academic Centre, Room 3.52, FranklinWilkins Building, Institute of Pharmaceutical Sciences, King's College London, 150 Stamford Street, London SW1 9NH, UK
The second issue in USA has been cornering of the market for certain drugs with egregious price gouging. It is becoming a pattern that a company that makes a relatively unique product that is essential for a small number of patients is taken over. The new management then massively increases the price without justification. The 'index' case arose late in 2015 (just after the deadline for last year's review). Martin Shrekli (formerly a hedge fund manager) acquired Turing Pharmaceuticals, and then increased the price of oral pyrimethamine (indicated for toxoplasmosis) from US $\$ 13.50$ to US\$750 per dose. Turing is the only supplier of this drug in USA, and toxoplasmosis is rare (usually a secondary complication of malignant disease or other causes of immunodeficiency) [4]. Meanwhile, in Canada, Mallinckrodt acquired Questcor in 2014 and its depot formulation of tetracosactide (an adrenocorticotropic hormone analog used to treat rare types of epilepsy in infants). The price charged to the provinces promptly rose from Can $\$ 33.05$ to Can $\$ 680$ per dose, albeit with the manufacturer claiming that US $\$ 50$ million was needed for a new production facility (reasons why the old facility was inadequate were unexplained) $[5,6]$. In what is essentially a free market (unlike most of the European payer systems), what is legal now seems to trump (pardon the pun) what is ethical in North America.

Third, on 14 May, 2016, the New York Times reported that Pfizer had become the last pharmaceutical manufacturer to ban the use of its products in executions [7]. Like all other manufacturers, both sides of the Atlantic, this is to be accomplished by strict tracking and restrictions on wholesalers and retailers. The threat is that if these restrictions are violated in any of the 32 US states that still have the death penalty, then all sales of the seven or eight drugs in question will be banned in that/those states. This would seriously hamper general anesthetics in those places. Those 38 states 
have responded with a certain amount of polemic and secrecy. Some states are discussing regression to electrocution, gunshot, or cyanide asphyxiation. It has also been suggested that the states are buying drugs via straw purchasers. Arkansas (in particular) claims to have a large stockpile. Within-state pharmacists are said to be willing to make extemporaneous formulations. At least one batch of drugs, imported from India, was seized at the port of entry by the FDA [7]. Texas claims that its drug sources must be kept secret to avoid violent threats to the pharmacies involved. Lawyers claim that this lack of transparency prevents checking compliance with the law; the use of adulterated or mislabeled products would constitute an illegal punishment. Perhaps those people who prescribe and dispense drugs for this purpose should be the next target.

And so we move to the second 'half' of the year, and the ' $\mathrm{B}$ ' word: Brexit! In June, as is well known, the UK voted to leave the European Union (EU). The reasons why have been well rehearsed. Everyone seems to have an opinion, including even someone in an epigenome regulation research center in the Far East, who believes that '... the immediate repercussions are devastating.' [8] In the UK, those on the losing side ('Remoaners') seem to hold the balance of the media coverage at present (October). However, in reality, the aftermath has not been devastating, and the stock markets have certainly not collapsed.

Cutting through the polemic, and regardless of one's political position, the fact is that the UK Government has now started down a path. We must assume that Brexit will occur. The implications for pharmaceutical medicine parse to two central issues. (1) What will be the UK's relationship with the European Medicines Agency (EMA), in terms of both regulation and geography? (2) What might be the impact on the UK pharmaceutical industry with regard to trade?

It is probably fair to say that the UK's contribution to the leadership and labor force at the EMA is larger than most of the other 27 European countries. One off-therecord estimate by a senior EMA officer was that 15-17\% of all the EMA-delegated review/rapporteur work is actually conducted by the Medicine and Healthcare products Regulatory Agency (MHRA), viz. the UK national competent authority in west London. Several senior EMA officers are also on secondment from the MHRA. While the EMA is probably a small consideration in the grand scheme of European divorce (compared, for example, with banking or trade regulatory bodies), the politicians will have to decide whether they are going to require the EMA to abandon this UK contribution to its work. Is it possible for a non-EU country to continue to operate its drugs policy under an EMA umbrella? In fact, the latter, to varying degrees, is already the case for Bermuda, the Channel Islands (Jersey, Guernsey, Alderney, and Sark), Iceland, Lichtenstein, and Norway. Some sort of accommodation along those lines might even obviate the need and expense of moving the EMA out of the Isle of Dogs (in east London).

Among highly technical areas, there are precedents for pan-European regulation outside the EU. For example, the European Court of Human Rights is perhaps the most conspicuous non-EU regulator. Furthermore, the non-EU Treaty of Vienna governs rights of residence for ex-patriots regardless of EU citizenship.

However, the current, hardline European political bellowing is that an EU institution must be physically located within the EU. A small-scale extension of this geographical imperative is that the Qualified Person for Pharmacovigilance and the Person Responsible for Scientific Services must also be within the EU at the same location as the pharmacovigilance master file. That cannot be insuperable: the large and small pharmaceutical companies in Switzerland must have already devised a solution.

The practical issues of relocating the EMA are not just cost. They would need a plan to replace the workload provided by the MHRA. There is currently no plan. Another off-the-record statement from a senior official is that Denmark is strongly lobbying for a relocated EMA in Copenhagen. By all accounts, this makes the EMA staff unhappy: they enjoy living in London, and do not want their children to have to learn Danish.

Practical issues require practical solutions. The obvious first choice is to carry on without change: drug regulation within the UK would remain as it now is. All the UK Parliament needs to do is masterly inactivity, i.e., not to repeal that part of the legislation. After all, EU legislation will not be wiped from the books at a single stroke upon 'Euro-divorce', but will remain statute law in the UK until each Act is separately and specifically repealed or amended by the UK Parliament.

As to trade, this is not a journal that concentrates on it. Neither am I a lawyer nor any other sort of expert in international trade. All one can observe, from a common sense point of view, is that if Actelion, Novartis, and Roche can trade from non-EU Switzerland into the EU, then why can't GSK and Astra Zeneca from a non-EU UK?

The EU prohibits individual countries from negotiating their own trade deals. However, the EU has also found it difficult to negotiate deals on behalf of the 27 countries. Most recently and spectacularly is the failure to reach a deal with the USA after 10 years of negotiation [9]. One reason for this is that 27 governments have to agree on the deal terms. In the case of the EU-USA deal, Bulgaria has vetoed the idea because Bulgarians must have visas to travel to USA! It is true that one small deal has been done with South Korea. That small deal is without the corresponding requirement of free movement of people between the EU and Korea [10], which is what is currently being 
demanded of the post-EU UK by European hardliners. There is also certainly no free movement of people and employment between non-EU Switzerland and the EU and yet there is an EU-Switzerland trade deal. A UK that escapes from the EU will be able to negotiate free trade deals of its own. If global free trade is the overall goal, then the UK might find that it is a good deal easier to achieve it post-Brexit, than when it was inside the EU; pharmaceuticals might not have to be an exception.

Last, amongst all the hullaballoo of this quarter that has seemed like half a year, it should be noted that on 15 August the FDA approved another biosimilar [11]. In this case, it is an etanercept-like product. Interestingly, this biosimilar approval specifies that the new product is not interchangeable with the original etanercept. The logic is unclear.

So, what is in store for next year? A 2-year horizon may be better, and the EMA situation will evolve. At the microlevel, it is possible that the EMA portal for clinical trials will finally come online, and that, for all practical purposes this will allow implementation of the clinical trials regulation 536/2014. Further, let us hope that the FDA finds approving biosimilars to be a bit more routine.

Happy New Year!

\section{Compliance with Ethical Standards}

Funding No funding was provided for the publication of this work.

Conflict of interest Tony Fox declares that he has no conflicts of interest. He holds no stock in any company that is marketing pharmaceutical products, and he has received no emoluments, of any type, from such a company for at least the past 5 years.

\section{References}

1. Upshur CC, Luckmann RS, Savageau JA. Primary care provider concerns about management of chronic pain in community clinic populations. J Gen Int Med. 2006;21:652-5.
2. Meier B. Opioid prescribing gets another look as FDA revisits mandatory doctor training. New York Times, 2 May, 2016, p. B1. Available from: http://www.nytimes.com/2016/05/03/business/ fda-again-reviews-mandatory-training-for-painkiller-prescribers. html?_r=0. Accessed 14 May 2016.

3. US Food and Drug Administration. Califf, FDA top officials call for sweeping review of agency opioid policies. FDA News Release, 4 Feb, 2016. Available from: http://www.fda.gov/ NewsEvents/Newsroom/PressAnnouncements/ucm484765.htm. Accessed 14 May 2016.

4. Pollack A, Creswell J. Martin Shrekli, the mercurial man behind the drug price that went viral. New York Times, 22 Sep, 2015. Available from: http://www.nytimes.com/2015/09/23/business/ big-price-increase-for-an-old-drug-will-be-rolled-back-turing-chiefsays.html?_r=0. Accessed 15 May 2016.

5. Robbins R. How a price hike for a drug for infants with epilepsy drove an uproar. STAT, 17 Nov, 2015. Available from: https:// www.statnews.com/2015/11/17/infants-epilepsy-drug-price/. Accessed 14 May 2016.

6. Mallinckrodt Pharmaceuticals. Mallinckrodt provides Synacthen ${ }^{\circledR}$ Depot and Synacthen update [media release]. 17 Nov, 2015. Available from: http://www.mallinckrodt.com/about/newsand-media/2113216. Accessed 14 May 2016.

7. Eckholm E. Pfizer prohibits use of its drugs for executions. New York Times, 14 May, 2016. p. A1.

8. Song $\mathrm{CH}$. Understanding the aftermath of Brexit: implications for the pharmaceutical industry. Pharmaceut Med. 2016;30:253-6.

9. Jordans F. German economy minister says EU-US trade talks have failed. 28 Aug, 2016. Available from: http://bigstory.ap.org/ article/611ff828b5ed44d5ad56ab46e0781e52/german-economyminister-says-eu-us-trade-talks-have-failed?utm_campaign=Social Flow\&utm_source=Twitter\&utm_medium=AP. Accessed 15 Oct 2016.

10. European Commission. The EU-Korea Free Trade Agreement in practice. Available from: http://trade.ec.europa.eu/doclib/docs/ 2011/october/tradoc_148303.pdf. Accessed 10 Oct 2016.

11. US Food and Drug Administration. FDA approves Erelzi, a biosimilar to Enbrel [media release]. 30 Aug, 2016. Available from: http://www.fda.gov/NewsEvents/Newsroom/PressAnnouncements/ ucm518639.htm. Accessed 1 Oct 2016. 